\title{
RAPId Diagnosis of Resistance to Imidazolinone HeRBICIDES IN BARNYARDGRASS (Echinochloa crus-galli) AND CONTROL OF RESISTANT BIOTYPES WITH ALTERNATIVE HERBICIDES ${ }^{1}$
}

\author{
Rápido Diagnóstico da Resistência a Herbicidas Imidazolinonas em Capim-Arroz (Echinochloa \\ crus-galli) e Controle de Biótipos Resistentes com Herbicidas Alternativos
}

\author{
MATZENBACHER, F.O..$^{2,3}$, KALSING, A. ${ }^{3}$, MENEZES, V.G. ${ }^{3}$, BARCELOS, J.A.N. ${ }^{2}$, and MEROTTO \\ JUNIOR, A. ${ }^{2}$
}

\begin{abstract}
The resistance of barnyardgrass (Echinochloa crus-galli) to imidazolinone herbicides is a worldwide problem in paddy fields. A rapid diagnosis is required for the selection of adequate prevention and control practices. The objectives of this study were to develop expedite bioassays to identify the resistance to imidazolinone herbicides in barnyardgrass and to evaluate the efficacy of alternative herbicides for the post-emergence control of resistant biotypes. Three experiments were conducted to develop methods for diagnosis of resistance to imazethapyr and imazapyr + imazapic in barnyardgrass at the seed, seedling and tiller stages, and to carry out a pot experiment to determine the efficacy of six herbicides applied at post-emergence in 13 biotypes of barnyardgrass resistant to imidazolinones. The seed soaking bioassay was not able to differentiate the resistant and susceptible biotypes. The resistance of barnyardgrass to imidazolinones was effectively discriminated in the seedlings and tiller bioassays seven days after incubation at the concentrations of 0.001 and $0.0001 \mathrm{mM}$, respectively, for both imazethapyr and imazapyr + imazapic. The biotypes identified as resistant to imidazolinones showed different patterns of susceptibility to penoxsulam, bispyribac-sodium and pyrazosulfuron-ethyl, and were all controlled with profoxydim and cyhalofop-butyl. The seedling and tiller bioassays are effective in the diagnosis of barnyardgrass resistance to imidazolinone herbicides, providing an on-season opportunity to identify the need to use alternative herbicides to be applied at post-emergence for the control of the resistant biotypes.
\end{abstract}

Keywords: bioassays, imazethapyr, imazapyr, imazapic, rice.

RESUMO - A resistência de capim-arroz (Echinochloa crus-galli) aos herbicidas imidazolinonas é um problema crescente na cultura do arroz em diversas regiões do mundo, sendo necessário o seu diagnóstico rápido para a determinação de práticas de prevenção e controle. Os objetivos deste trabalho foram desenvolver métodos de identificação expedita da resistência de biótipos de capimarroz aos herbicidas imidazolinonas e avaliar a eficácia de herbicidas alternativos para o seu controle em pós-emergência. Para isso, foram conduzidos três experimentos visando o desenvolvimento de métodos de diagnóstico da resistência aos herbicidas imazethapyr e imazapyr + imazapic em plantas de capim-arroz nos estádios de semente, plântula e perfilhos, bem como um experimento para determinar a eficácia de seis herbicidas em pós-emergência no controle de 13 biótipos de capim-arroz resistentes às imidazolinonas. A resistência de capim-arroz a imidazolinonas foi discriminada de forma eficiente

Recebido para publicação em 17.7.2012 e aprovado em 13.12.2012.

2 Federal University of Rio Grande do Sul - UFRGS, Av. Bento Gonçalves 7712, 91501-970 Porto Alegre-RS, Brazil, <felipematzenbacher@gmail.com>; <joseari.nene@gmail.com>; <merotto@ufrgs.br>; ${ }^{3}$ Researcher, M.Sc., Rice Institute of Rio Grande do Sul, IRGA, Av. Bonifácio Carvalho Bernardes 1494, 94930-030 Cachoeirinha-RS, Brazil, <augustokalsing@gmail.com>; <vmgaedke@yahoo.com.br>. 
nos experimentos com plântulas e perfilhos aos sete dias após a incubação nas concentrações de 0,001 e 0,0001 mM, respectivamente, para os herbicidas imazethapyr e imazapyr + imazapic. Os biótipos identificados como resistentes a imidazolinonas apresentaram diferentes padrões de suscetibilidade aos herbicidas penoxsulam, bispyribac-sodium e pyrazosulfuron-ethyl e somente foram controlados de modo eficaz com os herbicidas profoxydim e cyhalofop-butyl. Os bioensaios de plântulas e perfilhos são eficientes para o diagnóstico de capim-arroz resistente a imidazolinonas na mesma safra de desenvolvimento da cultura do arroz e proporcionam a identificação da necessidade de uso de herbicidas alternativos a serem aplicados em pós-emergência para o controle de biótipos resistentes.

Palavras-chave: bioensaios, imazethapyr, imazapyr, imazapic, arroz.

\section{INTRODUCTION}

The negative interference caused by weeds is a major factor limiting the productive potential of irrigated rice in Brazil and worldwide. Barnyardgrass (Echinochloa crusgalli) occurs with great frequency and distribution in all rice-producing regions and is one of the main weeds infesting paddy fields in southern Brazil (Andres et al., 2007). This weed is highly competitive with rice due to its adaptation to flooded environments, high seed production, rapid growth and C4-photosynthetic pathway (Marambe \& Amarasingle, 2002). Moreover, the large selection pressure caused by the use of acetolactate synthase (ALS)inhibiting herbicides developed the resistance of barnyardgrass biotypes to these herbicides in irrigated rice in southern Brazil (Merotto Jr. et al., 2009b; Mariot et al., 2010).

The diagnosis of weed resistance prior to the time of herbicide application or the confirmation of the resistance in uncontrolled plants are information required for the decision-making strategies to be used on the current or in the next crop season (Escorial et al., 2001). The early identification of herbicide resistance can avoid an increase in costs by reducing the number of herbicide applications, and especially for providing the choice of herbicide that provides adequate weed control (Kadum et al., 2011). The most important measure of prevention and control of resistant weed biotypes is the alternation of the mechanism of action in order to reestablish the effective chemical control. This procedure depends on the confirmation of the herbicide resistance in the field where failure of herbicide efficacy is suspected to occur.
The conventional method of confirmation of weed herbicide resistance is the evaluation of plant response to increasing herbicide doses sprayed on plants grown in pots or in the field (Burke et al., 2006; Corbett \& Tardif, 2006). However, resistance can also be identified by enzyme activity through molecular markers (Merotto Jr. et al., 2009a; Roso et al., 2010). The comparison of biotypes with suspected resistance and susceptible biotypes by the conventional, molecular or biochemical methods is usually time and labor consuming as well as expensive. These limitations can hinder the identification of resistance in a large number of samples if the result is to be achieved in the short run, and the collection of seeds from suspected resistant plants is required for later identification. In this scenario, the diagnosis of resistance is possible only after the harvest period, and the information will be used in the next crop season.

Rapid methods for diagnosis of different levels of weed resistance have been developed in Petri dishes, germination in rolled-paper, culture medium containing agar, herbicide solution in hydroponic conditions, among others (Letouze \& Gasquez, 2000; Kim et al., 2000; Burke et al., 2006). These methods are more useful because they offer greater reliability, lower cost, and shorter time for the discrimination of herbicide resistance. For example, the resistance of Lolium spp. to acetyl CoA carboxylase (ACCase)-inhibiting herbicides was evaluated in an agar bioassay for seedling growth and identified in 10 days after herbicide treatment (Kaundun et al., 2011). In another study, the resistance of red rice to imidazolinone herbicides could be 
identified in seven days after incubation in seedling and tiller bioassays, and this allowed the rapid identification of resistance and proved useful for decision-making in crop management (Roso et al., 2010). Several other studies were conducted in the last decade regarding the confirmation of herbicide resistance in weeds, including Echinochloa spp. (Kim et al., 2000; Andres et al., 2007; Concenço et al., 2008). The resistance of Echinochloa spp. to quinclorac was discriminated using foliar spray in greenhouse and growth chamber experiments (Andres et al., 2007; Concenço et al., 2008). The resistance to fenoxaprop-Pethyl and propanil in Echinochloa colona was identified in seven days by considering the seedling and root growth of adult plants incubated in herbicide solution (Kim et al., 2000). However, to our knowledge, there are no studies focusing on the identification of barnyardgrass resistant to imidazolinone herbicides through rapid bioassays. These compounds are one of most important tools for weed control in rice in Brazil, USA and in several regions where imidazolinoneresistant rice cultivars are used (Menezes et al., 2009). The rapid diagnosis of resistance to imidazolinone herbicides may have a direct benefit to rice farmers in these regions where the continued use of imidazolinone herbicides resulted in the evolution of resistant biotypes. The objectives of this study were to develop rapid bioassays to diagnose resistance to imidazolinone herbicides in barnyardgrass at stages of seeds, seedlings and tillers, and evaluatethe efficacy of alternative post-emergence herbicides for the control of imidazolinone resistant biotypes of barnyardgrass.

\section{MATERIALS AND METHODS}

\section{Bioassays for the diagnostic of imidazolinone resistance in barnyardgrass}

The bioassays of seed soaking, growth of seedlings and tillers were conducted as a factorial experiment in a completely randomized design with four replications. For each bioassay, factor A consisted of the susceptible barnyardgrass biotype, originated from area with an efficient control with imidazolinone herbicides, and the resistant biotype previously described by Merotto Jr. et al. (2009b). Factor B consisted of imazethapyr (Plus Nortox imazethapyr ${ }^{\circledR}, 106 \mathrm{~g} \mathrm{~L}^{-1}$ ) and imazapyr + imazapic $\left(\right.$ Kifix $^{\circledR}, 525$ and $175 \mathrm{~g} \mathrm{~kg}^{-1}$ ) at concentrations of $0,0.00001,0.0001,0.001$, $0.01,0.1,1.0,10$ and $100 \mathrm{mM}$. The concentration of imazapyr + imazapic refers to the molecular weight of imazapyr in the commercial mixture Kifix $^{\circledR}$. Initially, seeds were exposed to the interruption of dormancy in a moist chamber for 4 days. After that, for the bioassays of seedling and tillers, the seeds were soaked in water in Petri dishes in a growth chamber at constant temperature of $30{ }^{\circ} \mathrm{C}$ for four days. The germinated seeds were grown in pots containing Haplic Gleysol until the desired stages and one pot consisted of the experimental units for the experiments of growth of seedlings and tillers. In the seed soaking experiment, each experimental unit consisted of approximately 100 seeds that remained embedded in $50 \mathrm{~mL}$ of herbicide solution for 24 hours. After that, the seeds were transferred to rolled germination paper and kept in containers filled with approximately $2 \mathrm{~cm}$ of water. The experimental material was maintained in a growth chamber at a temperature of $25{ }^{\circ} \mathrm{C}$. Germination percentage and root length were measured at seven days after incubation. The seedlings of each repetition were photographed with a digital camera with five mega pixel resolution on a black background for estimation of root length. A standard ruler was photographed together with the seeds as a standard for comparison. Root length was quantified by using the software IMAGE J (Rasband, 1997).

The seedling bioassay was established using seedlings with two to three expanded leaves that were removed from the soil, rinsed, gently dried and weighted to obtain the variation of fresh weight before and after the herbicide incubation. The seedlings were placed in $50 \mathrm{~mL}$ recipients containing the herbicide solution of each treatment and maintained in a growth chamber at a temperature of $25{ }^{\circ} \mathrm{C}$. The herbicide solution was replaced four days later in order to avoid the herbicide concentration from increasing. The variables analyzed at seven days after the herbicide treatments were the change in fresh weight before and after incubation, and visual 
plant injury at percentage scale, where zero is the absence of herbicide effect and $100 \%$ represents the complete death of the plants.

The tiller bioassay was based on plants at the six-leaf stage. Plants were removed from the soil and washed, and the tillers were separated from the main stem. The main tillers were placed in $250 \mathrm{~mL}$ containers with a solution containing the herbicide treatments for a period of seven days. The root dry weight of each tiller was evaluated at the end of the experimental period. The roots were detached from the stem and dried at $60^{\circ} \mathrm{C}$ until constant weight.

\section{Alternative herbicides to control imidazolinone resistant barnyardgrass biotypes}

The study was carried out as a factorial experiment in completely randomized design with four replications. Factor A consisted of 13 biotypes collected from irrigated rice fields in different regions of the state of Rio Grande do Sul. Factor B consisted of herbicides profoxydim (Aura ${ }^{\circledR}, 200 \mathrm{~g} \mathrm{~L}^{-1}$ ), cyhalofop-butyl (Clincher ${ }^{\circledR}, 180 \mathrm{~g} \mathrm{~L}^{-1}$ ), quinclorac (Quinclorac ${ }^{\circledR}$, $500 \mathrm{~g} \mathrm{~L}^{-1}$ ), penoxsulam (Ricer ${ }^{\circledR}, 240 \mathrm{~g} \mathrm{~L}^{-1}$ ), bispyribac-sodium (Nominee ${ }^{\circledR}, 400 \mathrm{~g} \mathrm{~L}^{-1}$ ) and pyrazosulfuron-ethyl (Sirius ${ }^{\circledR}, 250 \mathrm{~g} \mathrm{~L}^{-1}$ ) at doses of 160, 180, 375, 48, 40 and $20 \mathrm{~g} \mathrm{ha}^{-1}$, respectively, with a non-ionic adjuvant at $1 \% \mathrm{v} \mathrm{v}^{-1}$.

The experimental units consisted of $500 \mathrm{~mL}$ plastic plots filled with soil loam Haplic Gleysol Ta. The soil was collected in the layer of $0-10 \mathrm{~cm}$ with $150 \mathrm{~g} \mathrm{~kg}^{-1}$ of clay, $1.5 \mathrm{dag} \mathrm{kg}^{-1}$ of organic matter, phosphorus greater than $100 \mathrm{mg} \mathrm{dm}^{-1}$ and potassium greater than $400 \mathrm{mg} \mathrm{dm}^{-1}$. Initially, seeds of each biotype were exposed to breaking dormancy as described earlier. After that, ten seeds of similar size were sown at two centimeters depth in each experimental unit. After emergence, the plants were thinned to two plants per experimental unit. The experiment was irrigated every two days with an amount of water equivalent to a rainfall of two millimeters.

The herbicide treatments were applied using a $\mathrm{CO}_{2}$ pressurized backpack sprayer maintained at a constant pressure of $40 \mathrm{lb} \mathrm{pol}^{-2}$, with flat nozzles type 110.03 , resulting in a spray volume of $120 \mathrm{~L} \mathrm{ha}^{-1}$. The herbicide application occurred when the plants of barnyardgrass reached the three-leaf stage, at a temperature of $24{ }^{\circ} \mathrm{C}$ and relative humidity of $84 \%$. After that, the experimental units were maintained with a water layer of $5 \mathrm{~cm}$ above the soil level, simulating the usual condition of paddy fields. The analyzed variables were visual plant injury at 21 days after treatment (DAT) and shoot dry weight at 28 DAT, as described earlier.

\section{Statistical analysis}

Data from the four experiments were initially subjected to analysis of variance (ANOVA). In the three bioassay experiments, the data were converted to percentage based on the untreated control. After that, the data were analyzed by nonlinear logistic regression of three or four parameters, using the statistical analysis "drc" of the R package (Knezevic et al., 2007). The comparison between the resistant and susceptible biotypes was performed using the resistance factor (RF), which is the ratio of the $\mathrm{GR}_{50}$ (growth reduction of $50 \%$ ) of the resistant biotype divided by the $\mathrm{GR}_{50}$ susceptible biotype, and the interval calculation confidence interval (CI) with 95\% significance. In the experiment with alternative herbicides for control of resistant biotypes, the complementary analysis was performed by the least significant difference (LSD), calculated by Student's t-test, using 5\% probability of experimental error as the limit of significance between the herbicides and biotypes evaluated.

\section{RESULTS AND DISCUSSION}

In the seed soaking bioassay, significant interaction $(p<0.001)$ was found between the factors biotypes and concentrations for seed germination. For root length, there was only a simple effect for the factors biotypes and herbicide concentrations $(\mathrm{p}<0.001)$. However, non-linear regression did not discriminate the resistance between susceptible and resistant biotypes for the herbicides imazethapyr for both variables (Figure 1A, C; Table 1) and for imazethapyr + imazapic (Figure 1B, D; Table 1). The resistance factor (RF) between 

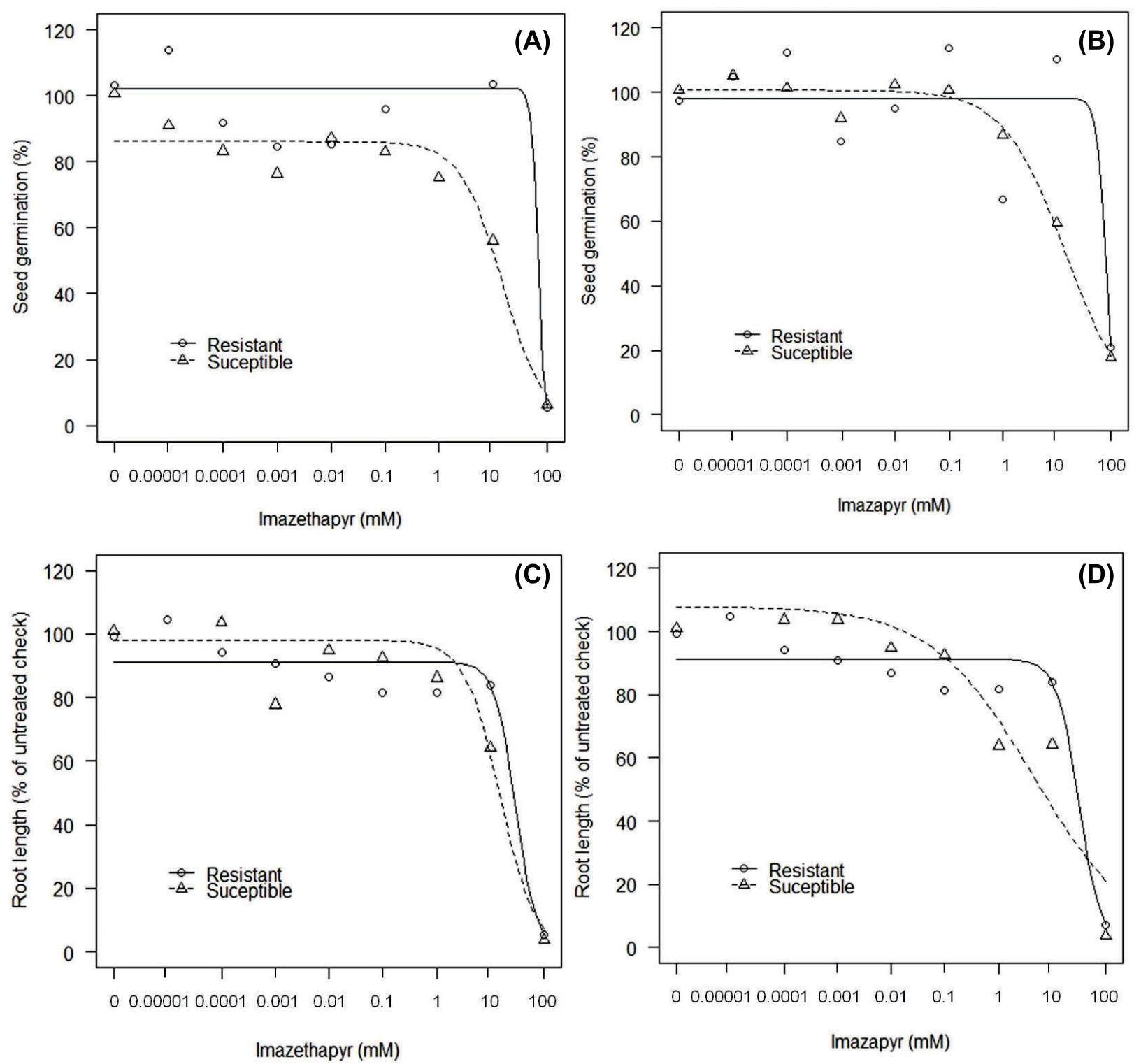

Figure 1 - Seed germination (A and B) and root length (C and D) as a proportion of the untreated check of barnyardgrass resistant and susceptible to imidazolinones in different concentrations of the herbicides imazethapyr (A and C) and imazapyr + imazapic (B and $\mathrm{D}$ ) evaluated in the seed soaking bioassay. Curves were adjusted by the logistic model, and the equation parameters are described in Table 1.

susceptible and resistant biotypes was not significant for either herbicide in the analysis of germination and root length (Table 1). The lack of significance of the regression parameters indicates that the evaluated variables in the seed soaking bioassay were not useful to diagnose imidazolinone resistance in barnyardgrass. Seed germination also was not effective for the discrimination of herbicide resistant and susceptible biotypes in a study with barnyardgrass resistant and susceptible to quinclorac (Andres et al., 2007). In a similar study with rice varieties resistant and susceptible to imidazolinones, seed germination was not a suitable parameter to discriminate herbicide resistance (Roso et al., 2010). Moreover, seed germination allowed the identification of the resistance of Monochoria vaginalis to imazosulfuron and pyrazosulfuronethyl (Kuk et al., 2003). In this study, the 
Table 1 - Parameters of the logistic equation and resistance factor $(\mathrm{RF})$ of seed germination percentage and root length of barnyardgrass resistant and susceptible to imidazolinones in the seed soaking bioassay at 7 DAT with different concentrations of the herbicides imazethapyr and imazapyr + imazapic

\begin{tabular}{|c|c|c|c|c|}
\hline Biotype & $b^{1^{\prime}}$ & $d^{2^{\prime}}$ & $e\left(\mathrm{GR}_{50}\right)^{\frac{3}{2}} \pm \mathrm{IC}^{4 /} 95 \%$ & $\mathrm{RF}^{5 /} \pm \mathrm{IC} 95 \%$ \\
\hline \multicolumn{5}{|c|}{ Seed germination $(\%)$} \\
\hline \multicolumn{5}{|c|}{ Imazethapyr } \\
\hline Resistant & $7.28^{\mathrm{NS}}$ & $102.21 * *$ & $67.18^{\mathrm{NS}}( \pm 541.69)$ & $4.53^{\mathrm{NS}}( \pm 36.60)$ \\
\hline Susceptible & $1.13^{\mathrm{NS}}$ & $86.14 * *$ & $14.85 *( \pm 9.14)$ & \\
\hline \multicolumn{5}{|c|}{ Imazapyr +imazapic } \\
\hline Resistant & $5.08^{\mathrm{NS}}$ & $98.10^{* *}$ & $77.65 *( \pm 57.67)$ & $5.47^{\mathrm{NS}}( \pm 5.01)$ \\
\hline Susceptible & $0.77 * *$ & $100.62 * *$ & $14.19 * *( \pm 7.57)$ & \\
\hline \multicolumn{5}{|c|}{ Root lenght $(\%)$} \\
\hline \multicolumn{5}{|c|}{ Imazethapyr } \\
\hline Resistant & $2.23 *$ & ble & $29.33^{\mathrm{NS}}( \pm 24.14)$ & $1.94^{\mathrm{NS}}( \pm 1.86)$ \\
\hline Susceptible & $1.33^{\mathrm{NS}}$ & $98.08 * *$ & $15.15 * *( \pm 7.50)$ & \\
\hline \multicolumn{5}{|c|}{ Imazapyr + imazapic } \\
\hline Resistant & $2.10 *$ & $91.26 * *$ & $31.41 *( \pm 21.43)$ & $6.93^{\mathrm{NS}}( \pm 7.71)$ \\
\hline Susceptible & $0.46 * *$ & $107.93 * *$ & $4.53^{\mathrm{NS}}( \pm 3.98)$ & \\
\hline
\end{tabular}

${ }^{1 /} b$ is the slope of the curve around the point of inflection; ${ }^{2} / d$ upper limit; ${ }^{3 /} e\left(\mathrm{G}_{50}\right)$ is herbicide concentration that decreases the response variable by $50 \%$; ${ }^{4 /}$ Confidence intervals at $95 \%$; ${ }^{5}$ Resistance factor: $\mathrm{GR}_{50}$ ratio between the resistant and susceptible biotypes. ${ }^{* *} p<0.01$; $* p<0.05$; ${ }^{\text {NS }}$ non-significant.

percentage of germination of the resistant biotype was 100 and 200 fold greater than the susceptible biotype when treated with herbicides imazosulfuron and pyrazosulfuronethyl, respectively. In another study, the diagnosis of glyphosate resistance in wheat and barley was effective at the seed stage through the analysis of coleoptile length at four days after treatment (Escorial et al., 2001).

The impossibility of resistance diagnosis through experiments with seeds of barnyardgrass found for Anders et al. (2007) and in the present study can be associated with the genetic variability of this weed compared, for example, to varieties of cultivated species. The high natural variability associated with the dormancy and vigor of seeds of barnyardgrass may have contributed to limiting the discrimination of herbicide resistance in seed soaking bioassays. In a study performed in Arkansas, USA, 67\% variation was found in the number of days to reach $100 \%$ germination of barnyardgrass seeds, depending on the year and the place of sampling (Bagavathiannan et al., 2011). In Argentina, a study with Echinochloa polystachya showed high genotypic variability in relation to the aboveground biomass of biotypes from different regions
(Pizarro, 1999). In another study, seeds of barnyardgrass showed variation in germination depending on age and duration of seed storage and plasticity between biotypes was identified as the cause of variation in seedling emergence (Martinkova et al., 2006). These results indicate that, in the case of species with large physiological and morphological variability, such as barnyardgrass, seed soaking bioassays may not be adequate to diagnose herbicide resistance. In addition, another factor that may be associated with the effectiveness of seed soaking for the diagnosis of herbicide resistance is seed size. Species with large seeds may have a more uniform germination and result in better discrimination of herbicide susceptible and resistance biotypes, as observed in wheat and barley (Escorial et al., 2001).

In the seedling bioassay, visual plant injury and fresh weight accumulation were significant for the interaction of biotypes and herbicide concentrations $(\mathrm{p}<0.0001)$. These variables were effective for the identification of barnyardgrass resistance to imazethapyr (Figures 2A, C; Table 2) and imazapyr + imazapic (Figures 2B, D; Table 2). The concentration that best discriminates 

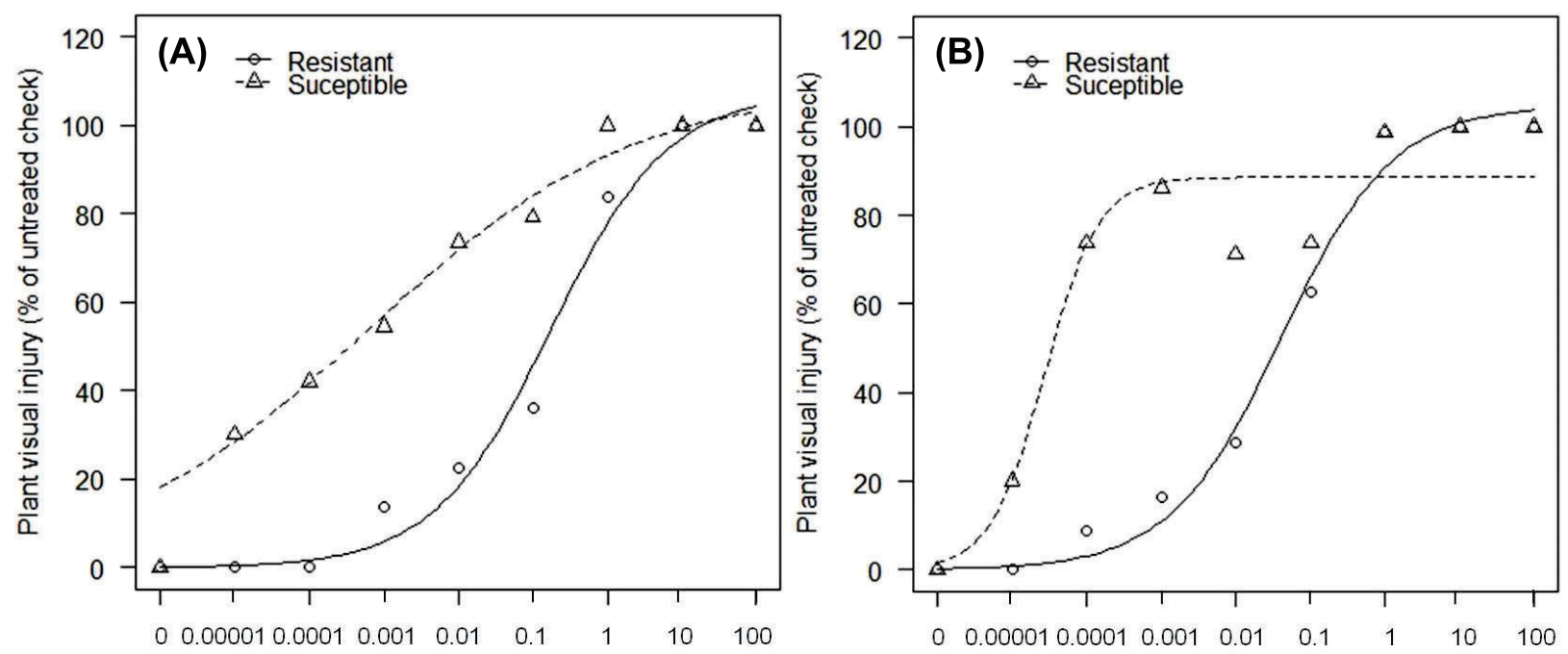

Imazethapyr (mM)
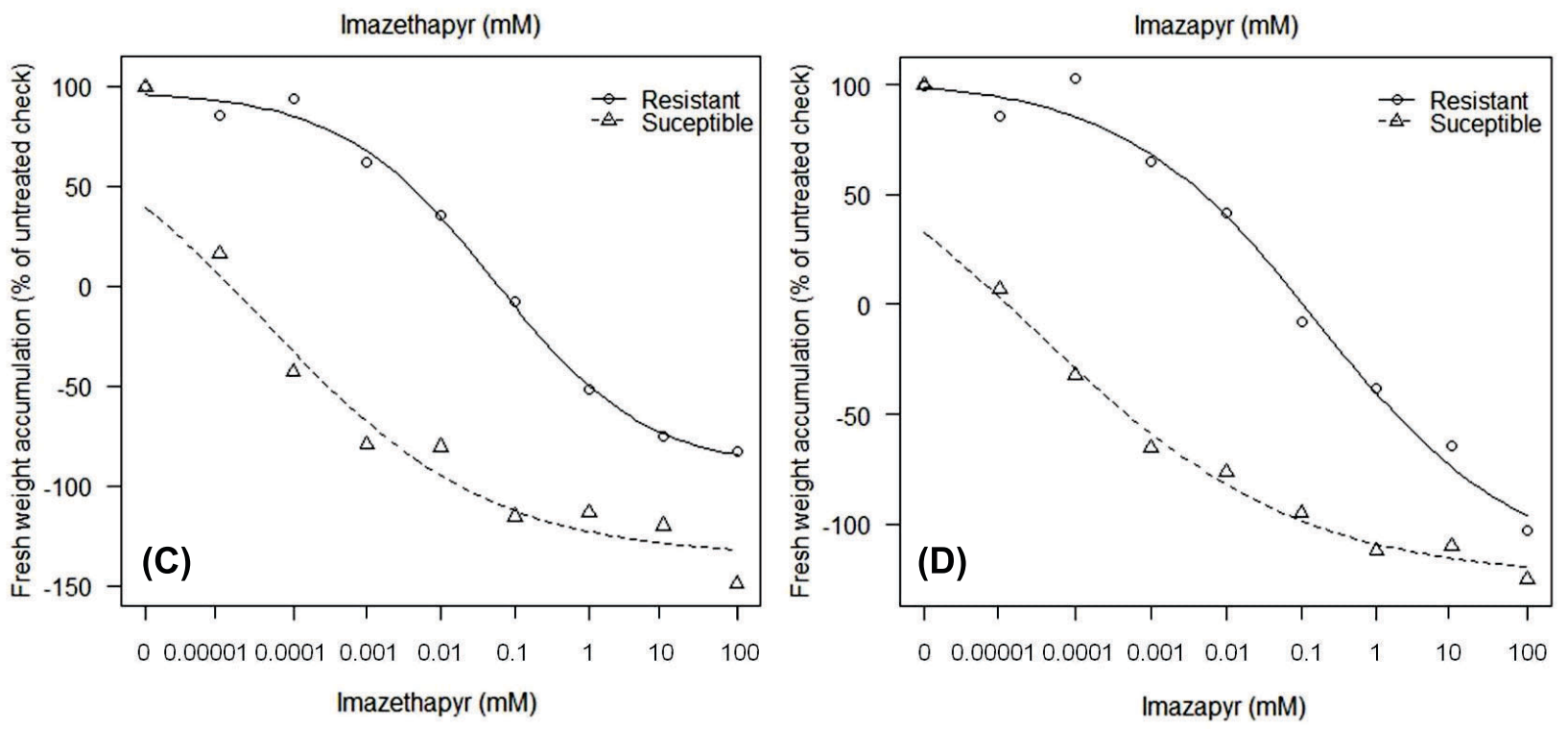

Figure 2 - Plant visual injury (\%) (A and B) and relative fresh weight accumulation (\%) (C and D) as a proportion of the untreated check of barnyardgrass resistant and susceptible to imidazolinones in different concentrations of the herbicides imazethapyr (A and C) and imazapyr + imazapic (B and D) evaluated in the seedling bioassay. Curves were adjusted by the logistic model, and the equation parameters are described in Table 2.

resistance was $0.001 \mathrm{mM}$ for both herbicides. The resistance factor between susceptible and resistant biotypes for the herbicide imazethapyr was 255 and 1288 for plant visual injury and fresh weight accumulation, respectively (Figures 2A, C; Table 2). For the herbicide imazapyr + imazapic the resistance factor was 1480 and 5585, respectively, for the same variables (Figures 2B, D; Table 2).

In the tillers bioassay, there was significant interaction between biotypes and herbicide concentrations for root dry weight $(\mathrm{p}<0.01)$. This variable was effective at discriminating herbicide resistance to imazethapyr (Figure 3A, Table 3) and imazapyr + imazapic (Figure 3B, Table 3) at the concentration of $0.0001 \mathrm{mM}$ to both herbicides. The RF among biotypes was 47 and 89 to imazethapyr and imazapyr + imazapic, respectively. In the seedling and tillers bioassays, the FR was higher for the herbicide imazapyr + imazapic compared to the herbicide imazethapyr. This was due to a lower magnitude of the parameters $\mathrm{GR}_{50}$ of 
Table 2 - Parameters of the logistic equation and resistance factor $(\mathrm{RF})$ to plant visual injury and relative fresh weight accumulation of barnyardgrass resistant and susceptible to imidazolinones in the seedling bioassay at 7 DAT of different concentrations of the herbicides imazethapyr and imazapyr + imazapic

\begin{tabular}{|c|c|c|c|c|c|}
\hline Biotype & $b^{1 /}$ & $c^{2 /}$ & $d^{3^{3 /}}$ & $e\left(\mathrm{GR}_{50}\right)^{4 /} \pm \mathrm{IC}^{\frac{5}{}} 95 \%$ & $\mathrm{RF}^{6 /} \pm \mathrm{IC} 95 \%$ \\
\hline \multicolumn{6}{|c|}{ Plant visual injury (\%) } \\
\hline \multicolumn{6}{|c|}{ Imazethapyr } \\
\hline Resistant & $-0.56 * *$ & - & $107.23 * *$ & $0.17 * *( \pm 0.05)$ & $254.89 *( \pm 194.14)$ \\
\hline Susceptible & $-0.25 * *$ & - & $108.72 * *$ & $0.0006 *( \pm 0.0006)$ & \\
\hline \multicolumn{6}{|c|}{ Imazapyr + imazapic } \\
\hline Resistant & $-0.58 * *$ & - & $104.82 * *$ & $0.04 *( \pm 0.02)$ & $1479.6 *( \pm 822.97)$ \\
\hline Susceptible & $-1.21 * *$ & - & $88.61 * *$ & $0.000027 * *( \pm 0.000008)$ & \\
\hline \multicolumn{6}{|c|}{ Relative fresh weight accumulation (\%) } \\
\hline \multicolumn{6}{|c|}{ Imazethapyr } \\
\hline Resistant & $0.42 * *$ & $-91.74 * *$ & $97.68 * *$ & $0.05 *( \pm 0.031)$ & $1288.35 * *( \pm 1039.75)$ \\
\hline Susceptible & $0.28 * *$ & $-135.40 * *$ & $100.99 * *$ & $0.0039 * *( \pm 0.00002)$ & \\
\hline \multicolumn{6}{|c|}{ Imazapyr + imazapic } \\
\hline Resistant & $0.33^{* *}$ & $-119.04 * *$ & $102.66^{* *}$ & $0.16 *( \pm 0.098)$ & $5584.50 * *( \pm 3953.63)$ \\
\hline Susceptible & $0.25 * *$ & $-124.69 * *$ & $100.43 * *$ & $0.00003 * *( \pm 0.00001)$ & \\
\hline
\end{tabular}

${ }^{1 /} b$ is the slope of the curve around the point of inflection; ${ }^{2 /} c$ lower limit; ${ }^{3 /} d$ upper limit; ${ }^{4 /} e\left(\mathrm{G}_{50}\right)$ is herbicide concentration that decreases the response variable by $50 \% ;{ }^{5}$ Confidence intervals at $95 \%$; ${ }^{6}$ Resistance factor: $\mathrm{GR}_{50}$ ratio between the resistant and susceptible biotypes $* * p<0.01 ; * p<0.05$; ${ }^{\text {Ns }}$ non-significant.
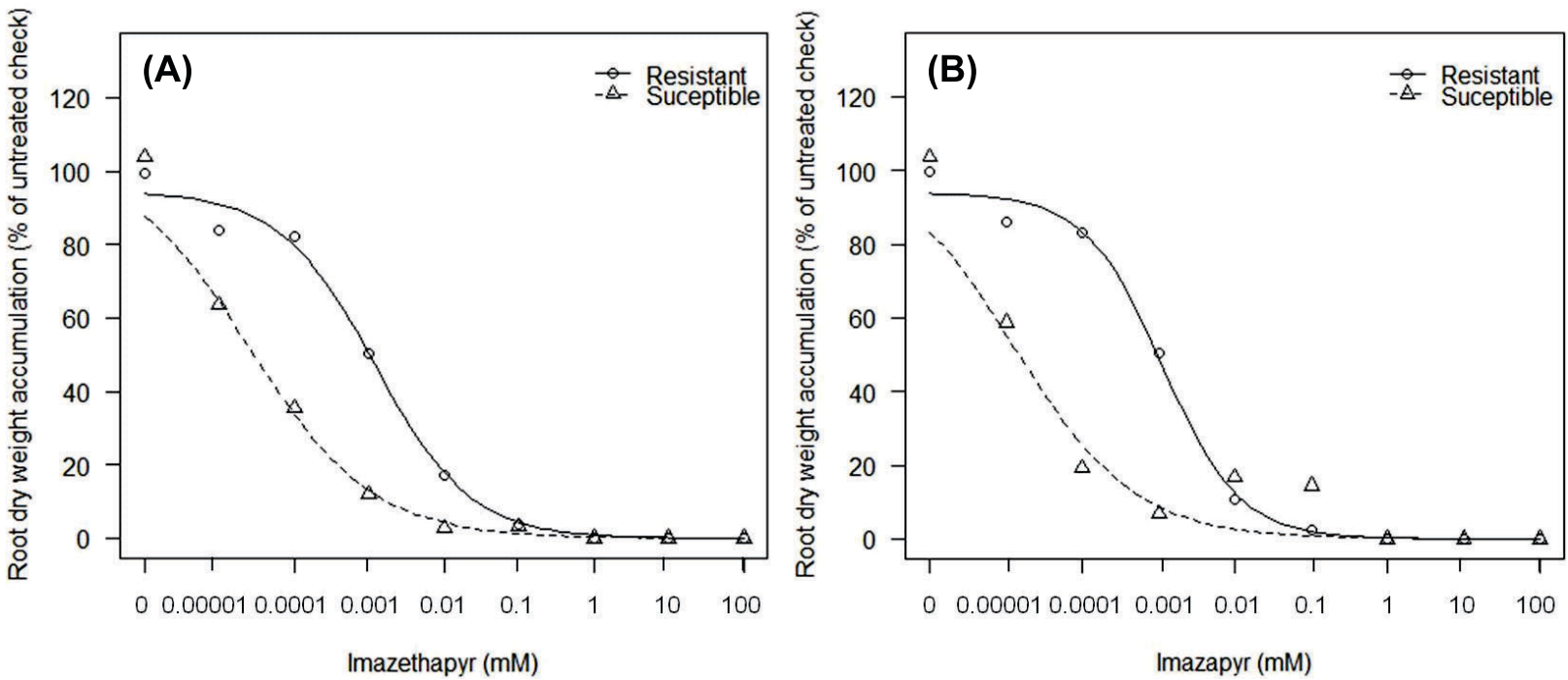

Figure 3 - Root dry weight of as a proportion of the untreated check of barnyardgrass resistant and susceptible to imidazolinones in different concentrations of the herbicides imazethapyr (A) and imazapyr + imazapic (B) evaluated in the tiller bioassay. Curves were adjusted by the logistic model, and the equation parameters are described in Table 3 .

the susceptible biotype in both variables, which provided the largest variation between resistant and susceptible biotypes. In similar studies of seedling and tillers bioassays carried out for other species and herbicides, the discrimination of susceptible and resistant biotypes was also successful. In studies with
Lolium spp. the resistance to ACCase inhibitors evaluated with seedlings grown in agar containing herbicide could be identified at 10 days after treatment (Kaundun et al., 2011). Furthermore, the identification of Sorghum halepense resistant to clethodim and fluazifopP-butyl herbicides in seedling bioassays 
Table 3 - Parameters of the logistic equation and resistance factor $(\mathrm{RF})$ to the root dry weight accumulation of barnyardgrass resistant and susceptible to imidazolinones in the tiller bioassay at 7 DAT with different concentrations of the herbicides imazethapyr and imazapyr + imazapic

\begin{tabular}{|c|c|c|c|c|}
\hline Biotype & $b^{1 /}$ & $d^{2 / 1}$ & $e\left(\mathrm{GR}_{50}\right)^{3 / /} \pm \mathrm{IC}^{4 /} 95 \%$ & $\mathrm{RF}^{5 /} \pm \mathrm{IC} 95 \%$ \\
\hline \multicolumn{5}{|c|}{ Imazethapyr } \\
\hline Resistant & $0.68 * *$ & $94.53 * *$ & $0.00119 * *( \pm 0.00042)$ & $47.23 * *( \pm 23.37)$ \\
\hline Susceptible & $0.53 * *$ & $103.63 * *$ & $0.000025 * *( \pm 0.0000085)$ & \\
\hline \multicolumn{5}{|c|}{ Imazapyr + imazapic } \\
\hline Resistant & $0.85 * *$ & $93.96 * *$ & $0.0011 *( \pm 0.0007)$ & $88.93 *( \pm 66.58)$ \\
\hline Susceptible & $0.55 *$ & $104.33 * *$ & $0.000013 * *( \pm 0.000005)$ & \\
\hline
\end{tabular}

$1 / b$ is the slope of the curve around the point of inflection; ${ }^{2} d$ upper limit; ${ }^{2} / e\left(\mathrm{G}_{50}\right)$ is herbicide concentration (mM) that decreases the response variable by $50 \% ;{ }^{4 /}$ Confidence intervals at $95 \% ;{ }^{5}$ Resistance factor: $\mathrm{GR}_{50}$ ratio between the resistant and susceptible biotypes. ${ }^{* *}$ $p<0.01 ; * p<0.05$; ${ }^{\text {NS }}$ Non-significant.

containing agar could be performed at five days of incubation (Burke et al., 2006). These studies indicated the effectiveness of the seedling and tiller bioassays for the rapid identification of weed species resistant to several herbicides.

One of the practical situations to obtain fast discrimination of herbicide resistance may be the dilution of the spray solution used at field conditions in order to obtain the recommended discriminatory concentration. The recommended field doses of $106 \mathrm{~g} \mathrm{ha}^{-1}$ of imazethapyr and $73.5+24.5 \mathrm{~g} \mathrm{ha}^{-1}$ of imazapic + imazapyr in a spray volume of $100 \mathrm{~L} \mathrm{ha}^{-1}$ are equivalent to concentrations of 3.66 and $2.81 \mathrm{mM}$, respectively. The discriminatory concentration of $0.001 \mathrm{mM}$ in the seedlings bioassay can be obtained by diluting the field spray solution in the proportion of $1 / 3668$ and $1 / 2816$ for the herbicides imazethapyr and imazapyr + imazapic, respectively. For the tiller bioassay, the discriminatory concentration of $0.0001 \mathrm{mM}$ can be obtained by the dilution of the spray solution in a proportion of $1 / 36678$ and $1 / 28161$, to imazethapyr and imazapyr imazapic, respectively. It should be noted that using this procedure identify herbicide resistance in barnyardgrass should ideally take place through the use of susceptible and resistant biotypes as a known standard for the comparison with the plants in the evaluation.

In the experiment of the evaluation of alternative herbicides to control barnyardgrass biotypes resistant to imidazolinones, there was significant interaction between biotypes and herbicides in both variables evaluated
(Table 4). The herbicides penoxsulam, bispyribac-sodium and pyrazosulfuron-ethyl did not provide effective control in most of the barnyardgrass biotypes evaluated (Table 4). This indicates that the biotypes of barnyardgrass selected by the imidazolinone herbicides are cross-resistant to the other herbicides described above, which had the same mechanism of action. However, different levels of control with these herbicides were observed among biotypes, where the herbicide penoxsulam was more effective in controlling ITAQU 16, ITAQU 17 and ITAQU18 biotypes in relation to other ALS inhibitor herbicides. Likewise, bispyribac-sodium, which is also an ALS inhibitor, was the most effective in controlling the biotypes ITAQU13, ITAQU14, ITAQU15, ITAQU19, ITAQU20, URUGU22 and URUGU23 than the other herbicides of the same mechanism of action. Superior efficacy of the ALS inhibitor pyrazosulfuron-ethyl was also observed in control MOSTS5 1 biotype compared to other herbicides of the same mechanism of action. The herbicides profoxydim and cyhalofop-butyl controlled all biotypes evaluated and can be used to control barnyardgrass resistant to imidazolinones. Quinclorac also provided high level of control of most of the biotypes evaluated, with the exception of biotype MOSTS51, who survived the application of this herbicide.

Variation in the cross-resistance pattern of the ALS-inhibiting herbicides was also observed in other species. Cyperus difformis, a biotype resistant to bensulfuronmethyl, orthosulfamuron, imazethapyr, 
propoxycarbazone bispyribac-sodium and sodium-penoxsulam, was susceptible to halosulfuron-methyl (Merotto Jr. et al., 2009a). In addition, twelve different cross-resistance patters to the chemical groups of five ALS inhibitors were observed in 56 biotypes of this species (Merotto Jr. et al., 2010). Other studies with C. difformis found cross-resistance to bensulfuron-methyl, cinosulfuron, imazamox and bispyribac-sodium, and susceptibility to halosulfuron-methyl (Busi et al., 2006). In
Arabidopsis thaliana, was also observed variation of the patterns of resistance among 22 ALS inhibitors evaluated (Roux et al., 2005). The different cross-resistance pattern to ALS-inhibitors found in this study and other studies indicated the complexity and variability of the resistance to these herbicides that may be associated with the differential ability of the herbicide detoxification or of the conformational structure of the ALS enzyme in different weed biotypes.

Table 4 - Plant visual injury (\%) at 21 DAT and aboveground dry weight at 28 DAT of barnyardgrass biotypes resistant to imidazolinone herbicides treated with different herbicides applied at post-emergence

\begin{tabular}{|c|c|c|c|c|c|c|c|}
\hline Biotype & $\begin{array}{l}\text { Untreated } \\
\text { check }\end{array}$ & Penoxsulam & $\begin{array}{l}\text { Bispyribac- } \\
\text { sodium }\end{array}$ & $\begin{array}{l}\text { Pyrazosulfuron- } \\
\text { ethyl }\end{array}$ & Profoxydim & $\begin{array}{l}\text { Cyhalofop- } \\
\text { butyl }\end{array}$ & Quinclorac \\
\hline \multicolumn{8}{|c|}{ Plant visual injury (\%) } \\
\hline ITAQU13 & E $0 a^{1 /}$ & D $57 \mathrm{~d}$ & B 77 a & D $55 \mathrm{~b}$ & A 80 a & A 80 a & C 70 d \\
\hline ITAQU14 & E 0 a & C $60 \mathrm{c}$ & B $75 b$ & D $55 \mathrm{~b}$ & A $78 \mathrm{~b}$ & $\mathrm{AB} 77 \mathrm{c}$ & $\mathrm{C} 60 \mathrm{~g}$ \\
\hline ITAQU15 & $\mathrm{F} 0 \mathrm{a}$ & E $5 \mathrm{i}$ & $\mathrm{C} 40 \mathrm{f}$ & D $10 \mathrm{i}$ & A 80 a & A 80 a & B $77 \mathrm{~b}$ \\
\hline ITAQU16 & $\mathrm{F} 0 \mathrm{a}$ & E $10 \mathrm{~g}$ & C $60 \mathrm{~d}$ & D $17 \mathrm{~h}$ & A $77 \mathrm{~b}$ & A $77 \mathrm{c}$ & B $72 \mathrm{c}$ \\
\hline ITAQU17 & E $0 \mathrm{a}$ & D $5 \mathrm{i}$ & C $35 \mathrm{~h}$ & B $38 \mathrm{~d}$ & A 80 a & A 78 bc & A $78 \mathrm{~b}$ \\
\hline ITAQU18 & E 0 a & $\mathrm{E} 0 \mathrm{j}$ & D $37 \mathrm{~g}$ & C $42 \mathrm{c}$ & A 80 a & A 80 a & B $66 \mathrm{f}$ \\
\hline ITAQU19 & E $0 \mathrm{a}$ & $\mathrm{D} 7 \mathrm{~h}$ & B $58 \mathrm{e}$ & $\mathrm{C} 10 \mathrm{i}$ & A 80 a & A 80 a & A $78 \mathrm{~b}$ \\
\hline ITAQU20 & $\mathrm{F} 0 \mathrm{a}$ & $\mathrm{E} 8 \mathrm{~h}$ & $\mathrm{C} 40 \mathrm{f}$ & D $23 \mathrm{~g}$ & B $73 \mathrm{~d}$ & B $75 \mathrm{~d}$ & A 80 a \\
\hline URUGU22 & E 0 a & D $40 \mathrm{e}$ & B 77 a & D $42 \mathrm{c}$ & A 80 a & $\mathrm{AB} 78 \mathrm{bc}$ & $\mathrm{C} 68 \mathrm{e}$ \\
\hline URUQU23 & $\mathrm{F} 0 \mathrm{a}$ & E $13 \mathrm{f}$ & C $35 \mathrm{~h}$ & D $28 \mathrm{f}$ & A 80 a & B $75 \mathrm{~d}$ & B $77 \mathrm{~b}$ \\
\hline CACHS50 & E $0 \mathrm{a}$ & D $63 \mathrm{~b}$ & C $68 \mathrm{c}$ & C 69 a & A 80 a & A 80 a & B $73 \mathrm{c}$ \\
\hline MOSTS51 & D $0 \mathrm{a}$ & B $40 \mathrm{e}$ & B $38 \mathrm{~g}$ & C $35 \mathrm{e}$ & A $77 \mathrm{~b}$ & A 78 bc & $\mathrm{D} 0 \mathrm{~h}$ \\
\hline SANTM52 & $\mathrm{F} 0 \mathrm{a}$ & D 67 a & $\mathrm{CD} 68 \mathrm{c}$ & E $37 \mathrm{~d}$ & B $75 \mathrm{c}$ & A 80 a & C $70 \mathrm{~d}$ \\
\hline \multicolumn{8}{|c|}{ Shoot dry weight (\%) } \\
\hline ITAQU13 & A $100.0 \mathrm{a}$ & B $15.6 \mathrm{~d}$ & $\mathrm{BC} 8.9 \mathrm{fg}$ & $\mathrm{C} 7.7 \mathrm{~g}$ & C $5.4 \mathrm{ab}$ & C $6.5 \mathrm{bc}$ & $\mathrm{BC} 8.1 \mathrm{bc}$ \\
\hline ITAQU14 & A $100.0 \mathrm{a}$ & B $21.3 \mathrm{~d}$ & D $6.5 \mathrm{~g}$ & C $14.3 \mathrm{fg}$ & CD 10.6 a & CD 9.4 bc & D $5.7 \mathrm{~b}$ \\
\hline ITAQU15 & A $100.0 \mathrm{a}$ & B $44.4 \mathrm{c}$ & C $21.2 \mathrm{de}$ & C 24.9 de & D $5.4 \mathrm{ab}$ & D 4.9 bc & D $4.7 \mathrm{~b}$ \\
\hline ITAQU16 & A $100.0 \mathrm{a}$ & B $61.3 \mathrm{~b}$ & C $25.3 \mathrm{cde}$ & DE 18.6 ef & EF $12.9 \mathrm{a}$ & CD $21.1 \mathrm{a}$ & F $7.0 \mathrm{~b}$ \\
\hline ITAQU17 & A $100.0 \mathrm{a}$ & B $49.4 \mathrm{c}$ & D $28.5 \mathrm{bcd}$ & C $36.0 \mathrm{c}$ & E $4.6 \mathrm{ab}$ & E 8.8 bc & E $3.1 \mathrm{~b}$ \\
\hline ITAQU18 & A $100.0 \mathrm{a}$ & B $72.1 \mathrm{a}$ & D $41.7 \mathrm{a}$ & C $55.8 \mathrm{a}$ & E $1.3 \mathrm{~b}$ & E $1.7 \mathrm{bc}$ & E $5.1 \mathrm{~b}$ \\
\hline ITAQU19 & A $100.0 \mathrm{a}$ & B $48.4 \mathrm{c}$ & D 18.1 ef & C $38.6 \mathrm{bc}$ & $\mathrm{F} 1.4 \mathrm{~b}$ & EF $2.8 \mathrm{c}$ & E $9.3 \mathrm{~b}$ \\
\hline ITAQU20 & A $100.0 \mathrm{a}$ & B $62.8 \mathrm{ab}$ & D $33.8 \mathrm{abc}$ & C $47.0 \mathrm{ab}$ & E $2.9 \mathrm{~b}$ & E $1.5 \mathrm{c}$ & E $2.8 \mathrm{~b}$ \\
\hline URUGU22 & A $100.0 \mathrm{a}$ & B $17.6 \mathrm{~d}$ & $\mathrm{CD} 6.8 \mathrm{~g}$ & $\mathrm{BC} 12.4 \mathrm{fg}$ & D $5.2 \mathrm{ab}$ & D 5.2 bc & D $4.8 \mathrm{~b}$ \\
\hline URUQU23 & A $100.0 \mathrm{a}$ & B $43.1 \mathrm{c}$ & C $26.8 \mathrm{bcd}$ & C $33.0 \mathrm{~cd}$ & D $4.8 \mathrm{ab}$ & D $4.3 \mathrm{bc}$ & D $2.9 \mathrm{~b}$ \\
\hline CACHS50 & A $100.0 \mathrm{a}$ & B $16.3 \mathrm{~d}$ & B $20.6 \mathrm{de}$ & B 17.7 ef & C $3.2 \mathrm{ab}$ & C $2.3 \mathrm{c}$ & C $5.5 \mathrm{~b}$ \\
\hline MOSTS51 & A $100.0 \mathrm{a}$ & E $20.0 \mathrm{~d}$ & D $36.8 \mathrm{ab}$ & C $48.7 \mathrm{a}$ & F $9.8 \mathrm{ab}$ & EF $13.1 \mathrm{ab}$ & B $59.2 \mathrm{a}$ \\
\hline SANTM52 & A $100.0 \mathrm{a}$ & B $14.9 \mathrm{~d}$ & B 18.0 ef & B $13.7 \mathrm{fg}$ & C $4.7 \mathrm{ab}$ & C $6.7 \mathrm{bc}$ & $\mathrm{C} 4.8 \mathrm{~b}$ \\
\hline
\end{tabular}

1/ Means followed by the same capital letter within lines and lower case letter within columns are not different by the DMS test at $5 \%$ of probability. 
Rapid diagnosis of imidazolinone resistance in barnyardgrass is achieved through the seedlings and tiller bioassays. The concentration of imazethapyr and imazapyr + imazapic that best differentiates resistant and susceptible biotypes is 0.001 and $0.0001 \mathrm{mM}$ in the bioassays with seedlings and tillers, respectively. The barnyardgrass biotypes resistant to imidazolinones showed variations in susceptibility to herbicides penoxsulam, bispyribac-sodium and pyrazosulfuron-ethyl. The herbicides profoxydim and cyhalofopbutyl were effective for post-emergence control of all biotypes identified as resistant to imidazolinone and are alternatives for the management of barnyardgrass resistant to ALS-inhibiting herbicides.

\section{ACKNOWLEDGEMENTS}

The authors are thankful to the Brazilian Council of Scientific and Technological Development (CNPq) and the Coordination for the Improvement of Higher Education Personnel (CAPES) for providing financial support and a scholarship to the first author.

\section{LITERATURE CITED}

ANDRES, A. et al. Detecção da resistência de capim-arroz (Echinochloa sp.) ao herbicida quinclorac em regiões orizícolas do sul do Brasil. Planta Daninha, v. 25, n. 1, p. 221-226, 2007.

BAGAVATHIANNAN, M. V. et al. Seedbank size and emergence pattern of barnyardgrass (Echinochloa crus-galli) in Arkansas. Weed Sci., v. 59, n. 3, p. 359-365, 2011.

BURKE, I. C. et al. A seedling assay to screen aryloxyphenoxypropionic acid and cyclohexanedione resistance in johnsongrass (Sorghum halepense)

Weed Technol., v. 20, n. 4, p. 950-955, 2006.

BUSI, R. et al. Patterns of resistance to ALS herbicides in smallflower umbrella sedge (Cyperus difformis) and ricefield bulrush (Schoenoplectus mucronatus). Weed Technol., v. 20, n. 4, p. 1004-1014, 2006

CONCENÇO, G. et al. Método rápido para detecção de resistência de capim-arroz (Echinochloa spp.) ao quinclorac. Planta Daninha, v. 26, n. 2, p. 429-437, 2008.

CORBETT, C. A. L.; TARDIF, F. J. Detection of resistance to acetolactate synthase inhibitors in weeds with emphasis on DNA-based techniques: A review. Pest Manag. Sci., v. 62, n. 7, p. 584-597, 2006.
ESCORIAL, M. C. et al. A rapid method to determine cereal plant response to glyphosate. Weed Technol., v. 15, n. 4, p. 697-702, 2001.

KAUNDUN, S. S. et al. Syngenta 'RISQ' test: a novel inseason method for detecting resistance to post-emergence ACCase and ALS inhibitor herbicides in grass weeds.

Weed Res., v. 51, n. 3, p. 284-293, 2011

KIM, D. S. et al. Rapid detection of propanil and fenoxaprop resistance in Echinochloa colona. Weed Sci., v. 48, n. 6, p. $695-700,2000$.

KNEZEVIC, S. Z. et al. Utilizing R software package for dose-response studies: The concept and data analysis. Weed Technol., v. 21, n. 3, p. 840-848, 2007.

KUK, Y. I. et al. Rapid diagnosis of resistance to sulfonylurea herbicides in monochoria (Monochoria vaginalis). Weed Sci., v. 51, n. 3 , p. $305-311,2003$

LETOUZE, A.; GASQUEZ, J. A pollen test to detect ACCase target-site resistance within Alopecurus myosuroides populations. Weed Res., v. 40, n. 2, p. 151-162, 2000.

MARAMBE, B.; AMARASINGHE, L. Propanil-resistant barnyardgrass [Echinochloa crus-galli (L.) Beauv.] in Sri Lanka: Seedling growth under different temperatures and control. Weed Biol. Manag., v. 2, n. 4, p. 194-199, 2002.

MARIOT, C.H.P. et al. Resistência múltipla e cruzada de capim-arroz aos herbicidas na cultura de arroz no Rio Grande do Sul. In: CONGRESSO BRASILEIRO DE PLANTAS DANINHAS, 27., 2010, Ribeirão Preto. Anais... Ribeirão Preto: SBCPD, 2010. p. 1455-1459.

MARTINKOVA, Z. et al. Seed age and storage conditions influence germination of barnyardgrass (Echinochloa crusgalli). Weed Sci., v. 54, n. 2, p. 298-304, 2006.

MENEZES, V. G. et al. Arroz-vermelho (Oryza sativa) resistente aos herbicidas imidazolinonas. Planta Daninha, v. 27, p. 1047-1052, 2009. (Número Especial)

MEROTTO JR., A. et al. Cross-resistance to herbicides of five ALS-inhibiting groups and sequencing of the ALS gene in Cyperus difformis L. J. Agric. Food Chem., v. 57, n. 4, p. 1389-1398, 2009a.

MEROTTO JR., A. et al. Distribution and cross-resistance patterns of ALS-inhibiting herbicide resistance in smallflower umbrella sedge (Cyperus difformis). Weed Sci., v. 58, n. 1, p. $22-29,2010$

MEROTTO JR., A. et al. Resistência de Capim-arroz (Echinochloa crusgalli) aos herbicidas inibidores da enzima ALS. In: CONGRESSO BRASILEIRO DE ARROZ IRRIGADO, 6., 2009, Porto Alegre. Anais... Porto Alegre SOSBAI, 2009b. 619 p.

Planta Daninha, Viçosa-MG, v. 31, n. 3, p. 645-656, 2013 
PIZARRO, H. Periphyton biomass on Echinochloa polystachya (HBK) hitch. of a lake of the Lower Parana River floodplain, Argentina. Hydrobiologia, v. 397, n. 0, p. 227-239, 1999.

RASBAND, W. S. ImageJ Software. 1997. Bethesda: U.S National Institutes of Mental Health. Disponível em: <http:// rsbweb.nih.gov/ij/>. Acesso em: 15 fev. 2011.
ROSO, A. C. et al. Bioensaios para diagnóstico da resistência aos herbicidas imidazolinonas em arroz. Planta Daninha, v. 28, n. 2 , p. $411-419,2010$

ROUX, F. et al. Response of Arabidopsis thaliana to 22 ALS inhibitors: baseline toxicity and cross-resistance of csr1-1 and csr1-2 resistant mutants. Weed Res., v. 45, n. 3, p. 220-227, 2005. 